\title{
O REINO DE DEUS E A CIDADE À LUZ DA SECULARIZAÇÃO
}

\section{ARTIGO ORIGINAL}

MACHADO, Ilo Rodrigo de Farias ${ }^{1}$

MACHADO, Ilo Rodrigo de Farias. O reino de Deus e a cidade à luz da secularização. Revista Científica Multidisciplinar Núcleo do Conhecimento. Ano 06, Ed. 07, Vol. 07, pp. 186-203. Julho de 2021. ISSN: 2448-0959, Link de acesso: https://www.nucleodoconhecimento.com.br/teologia/luz-da-secularizacao, DOI: 10.32749/nucleodoconhecimento.com.br/teologia/luz-da-secularizacao

\section{RESUMO}

A estreita relação entre a religião e o Estado nasce com a própria criação da cidade na qual a religião intervém em toda sua estrutura civil e política. $O$ advento do cristianismo apregoa uma mudança nessa relação uma vez que busca separar o poder político do poder religioso. Contudo, o Estado se apropria do cristianismo como um instrumento institucionalizado de governo. Essa proximidade entre a religião e o Estado, agora com a institucionalização do cristianismo, encontra oposição diante das diversas transformações sociais que levaram à emancipação do que era considerado "profano" da religião revelando a secularização como um fenômeno que reescreve os valores de uma sociedade livre da religião. O problema que se apresenta é saber, nesse contexto de secularização, qual a possível interação entre o Reino de Deus e o governo da cidade. Mediante o uso de pesquisa bibliográfica observou-se como resultado, que, em que pese a forte relação da religião com a cidade, há uma clara divisão entre ambos. Assim, como conclusão, o que se observou é que o Reino de Deus não se concretiza com a assunção de alguém no poder, nem, tampouco, pode ser percebido com a sua junção com o

\footnotetext{
${ }^{1}$ Mestrando Em Teologia, Especialista, Bacharel Em Teologia, Bacharel Em Direito.
}

RC: 91482

Disponível em: https://www.nucleodoconhecimento.com.br/teologia/luz-da- 
Estado. O Reino de Deus é o governo de Deus na vida do homem que se concretiza no próprio homem e não no Estado.

Palavras-chave: Secularização, Religião, Laicidade, Reino de Deus.

\section{INTRODUÇÃO}

A proximidade das relações entre o Estado e a Comunidade Religiosa é matéria que merece atenção tanto pelo fenômeno político/jurídico, como pelo fenômeno filosófico/teológico. Essa relação, em um ambiente plural, principalmente no Brasil, com maioria cristã, pode fazer colidir com os interesses legítimos entre os valores da Igreja e do Estado, como os casos referentes às uniões homoafetivas, ao aborto, ao divórcio etc.

A Relação do Cristianismo com a cidade, em que pese a evidente separação entre o reino deste mundo e o de Cristo, tornou-se estreitada, uma mistura entre o sagrado e o profano, fazendo com o que o Estado se apoderasse da fé cristã utilizando-a como base de seu controle social, criando um diálogo confuso entre os fundamentos da fé cristã e a pessoa do imperador.

Por esses motivos, pretende-se estudar a relação da religião com a cidade, criando um recorte necessário entre o que se pode perceber como Reino de Deus e sua relação com a cidade, mostrando, assim, o que, de fato, pode ser entendido como Reino de Deus.

\section{A RELIGIÃO E A CIDADE}

A história da relação do homem com o Estado, mesmo que de natureza predominantemente civil, teve como fundamento uma raiz religiosa. Era natural ao homem submeter-se aos comandos de seus governantes por entender que esses exerciam um papel divino a ser executado na terra por meio de suas ordens. A

RC: 91482

Disponível em: https://www.nucleodoconhecimento.com.br/teologia/luz-da- 
subordinação de um homem a outro, mesmo que diante de uma ligação genealógica, não se dava meramente por questões hierárquicas, a obediência era considerada em razão da veneração religiosa construída por seus ancestrais em comum.

Como quase todas as sociedades humanas se organizaram em algum ponto na forma tribal, muitos são tentados a crer que este é, de alguma forma, um estado de coisas natural ou de motivação biológica. Porém, não é evidente a razão pela qual você deveria cooperar com um primo em quarto grau em vez de com um conhecido sem parentesco só porque com o seu primo você tem em comum um sexagésimo quarto dos seus genes.

$[\ldots]$

O motivo pelo qual esta forma de organização social predominou entre as sociedades humanas foi a crença religiosa, isto é, a veneração de ancestrais mortos. [...] É a crença no poder dos ancestrais mortos sobre os vivos que leva as sociedades tribais a aderir, e não um misterioso instinto biológico. (FUKUYAMA, 2013, p. 78).

A união familiar não gerava apenas um laço sentimental entre os membros da família. A união se dava em razão da religião que era marcada pela crença comum dos antepassados, tornando a família antiga uma comunidade fortemente religiosa, conforme Coulange (1961), era uma associação mais voltada ao fogo sagrado e à religião do que uma simples união natural.

Destaca-se, assim, que, embora não tenha sido a religião aquela que efetivamente criou a família, foi ela quem a normatizou. A família, por sua vez, não se fez expandir por si, e com o passar do tempo transformou-se em cidade. Não se trata de um núcleo familiar que, expandido, gerou a cidade, ao contrário, a sociedade humana não se expandiu como um círculo único, ela é formada pela congregação de vários grupos, sendo certo que foi a perspectiva religiosa a respeito do culto que possibilitou essa nova associação para a expansão (COULANGES, 1961).

RC: 91482

Disponível em: https://www.nucleodoconhecimento.com.br/teologia/luz-da- 
A ligação religiosa existente dentro daquele núcleo familiar dificilmente permitiria que estranhos pudessem participar dessa ligação. A família, unida pelo sagrado, em princípio, não autorizaria a participação de terceiros. Com o tempo, a união de tribos tornou-se viável, sendo que essa viabilidade restou possível desde que respeitado o culto à divindade de cada um. Foi assim que diversos grupos, reunidos cada qual em torno de seu sagrado, estabeleceram alianças capazes de formar a cidade. Essa possibilidade de união, estabelecida com a aliança entre os membros de diversos grupos, torna-se o termo inicial da existência da cidade (COULANGES, 1961).

Como exemplo, as tribos do antigo Israel eram grupos de famílias, unidas por uma descendência comum, e que utilizavam o nome de seus antepassados precedido da palavra "filho":

A Tribo é um grupo autônomo de famílias que se consideram descendentes de um mesmo antepassado. Ela é denominada segundo o nome ou o sobrenome de seu antepassado, precedido ou não de "filhos de". Os exemplos árabes são inumeráveis. Na Bíblia, o grupo dos descendentes de Amaleque, de lidom, de Moabe, são chamados Amaleque, Edom, Moabe sem a adição de "filhos de". Contudo, se diz "Israel" ou "filhos de Israel", "Judá" ou "filhos de Judá" etc., e sempre "filhos de Amom", exceto dois casos, dos quais um é textualmente incerto. No lugar de "filhos", pode-se dizer "casa" (no sentido de família, descendência): "a casa de Israel", sobretudo, "a casa de José". (VAUX, 2003, p. 23).

O fundador realizava o ato religioso que permitiria a existência da própria cidade, sendo, por isso, respeitado e, quando morto, dedicavam-lhe culto. Poder-se-ia pensar que as instituições políticas surgiram apenas após esse ato religioso de criação da cidade, contudo, é de perceber que essas, as instituições políticas, nasceram de fato, com a própria cidade. Logo, é no nascedouro da cidade que sua estrutura social já se revela. Nesse sentido, por exemplo, assim como a família, reunida diante do sagrado, estabelecia um chefe, um sacerdote supremo, a cidade também deveria ter o seu sacerdote, alguém que sobre ela poderia exercer certa autoridade legitimada pela divindade. Por esses motivos, não causa estranheza que

RC: 91482

Disponível em: https://www.nucleodoconhecimento.com.br/teologia/luz-da- 
as normas que organizavam a cidade eram de dupla natureza, ou seja, eram de natureza religiosa e civil.

\begin{abstract}
Não nos devemos esquecer de que, nos tempos antigos, o que constituía o vínculo de toda sociedade era o culto. Assim como o altar doméstico mantinha unidos a seu redor os membros de uma família, assim o culto de uma cidade era a reunião daqueles que tinham os mesmos deuses protetores, e que celebravam os atos religiosos no mesmo altar. (COULANGE, 1961, p. 128).
\end{abstract}

Essa ligação entre a religião e a família foi importante para o nascedouro da própria cidade. Não foi a cidade criada para depois existir uma união em torno de uma divindade, ao contrário, foi a união em torno da(s) divindade(s) que se permitiu o protótipo da criação da cidade. Foi o vínculo religioso quem permitiu a formação da cidade. Em seu nascedouro, o que se tinha era uma cidade fortemente religiosa, marcada por uma legislação que misturava direitos profanos com direitos ligados às determinações de uma divindade. A subordinação de um membro sobre o outro se dava quase que exclusivamente por questões de crenças. Tais fatos ocorriam tendo em vista que se estava diante de uma cidade que surge em volta de uma crença divina e que coloca sobre si um administrador que mistura a figura do sacerdote com a figura do imperador.

Segundo Coulange (1961), fortemente religiosa, a cidade consistia em um lugar destinado aos sacrifícios. Conforme se cria na Grécia, era um lugar de banquetes públicos em torno da divindade, acreditando-se que a salvação adviria do banquete. Era a refeição um ato sagrado dentro da cidade. As festas também eram marcas religiosas que prevaleceram fortes. Existia a destinação de dias especiais que tinham por objetivo agradar aos deuses, fazendo com que tudo o que era sagrado virasse uma festa. Considerando esse número de eventos religiosos, os calendários eram, na verdade, uma sucessão de festas religiosas. Logo, os dias não se regulavam pelo sol e pela lua, mas pelas leis da religião que eram diferentes entre as cidades. Até mesmo as assembleias só eram possíveis mediante determinações da religião. As assembleias possuíam ritos, suas reuniões eram em templos, como

RC: 91482

Disponível em: https://www.nucleodoconhecimento.com.br/teologia/luz-da- 
no caso do Senado Roma, e a tribuna a ser utilizada era tida como um lugar sagrado.

Percebe-se, assim, que a cidade se tornou reflexo dos ritos religiosos das famílias antigas, ficando ligada a uma divindade com quem mantinha relação de subordinação, criando normas de natureza religiosa com efeitos civis, funcionando, desde sua criação, de modo politicamente estruturado em torno dos ritos da religião e elegendo para si um imperador com "poderes especiais" frente a divindade e a toda comunidade.

\section{OS EFEITOS DO CRISTIANISMO NA RELAÇÃO ENTRE A RELIGIÃO E A CIDADE}

O "modo de ser cidade" sofre uma profunda ressignificação com a presença do cristianismo, o que, de certa forma, facilitou o processo de desvinculação da figura do sacerdote com a do chefe de estado. O cristianismo não apenas surge como uma simples religião, mas também como uma visão religiosa que se fez vencedora frente aos outros modelos de religião, influenciando os modelos filosóficos de seu tempo, marcando o fim de uma era. A "vitória do cristianismo marca o fim da sociedade antiga" (COULANGES, 1961).

A mudança produzida pelo cristianismo se observa quando, de um dogma religioso em que cada povo possuía um (vários) deus (es) que o(s) protegia(m) de modo exclusivo, gerando normas que geririam as relações entre os homens, ou seja, de uma relação individualista de uma cidade (nação) com seu(s) deus(es) passou-se a um Deus universal, único, que atende, sozinho, a todos os mundos, colocando-o fora da natureza visível, ou seja, fora da cidade. Não se tratava mais de um Deus de apenas uma raça, mas de um Deus que alcançava o mundo de modo indistinto. Aos homens, em geral, v.g. o estrangeiro, criou-se reciprocidade em deveres de justiça. Em que pese a cidade e a religião serem unidas em uma só forma na antiguidade, com o cristianismo, considerando as obras de Jesus Cristo, houve a separação do

RC: 91482

Disponível em: https://www.nucleodoconhecimento.com.br/teologia/luz-da- 
império deste mundo do "império divino", ou seja, é com o cristianismo que surge a indicação da existência de um império divino que não seria deste mundo.

\begin{abstract}
Em lugar disso Jesus Cristo ensina que seu império não é deste mundo. Separa a religião do governo. Como a religião não é mais terrestre, imiscui-se nas coisas da terra o menos possível. Jesus Cristo acrescenta: "Dai a César o que é de César, e a Deus o que é de Deus." - É a primeira vez que se distingue tão nitidamente Deus do Estado. Porque César, nessa época era ainda o sumo pontífice, o chefe e órgão principal da religião romana; era o guarda e o intérprete das crenças; mantinha em suas mãos o culto e o dogma. Sua pessoa era sagrada e divina; porque constituía precisamente uma das características da política dos imperadores, desejosos de reconquistar os atributos da antiga realeza, não esquecer esse caráter divino que a antiguidade atribuíra aos reis-pontífices e aos sacerdotes-fundadores. Mas eis que Jesus Cristo quebra essa aliança que o paganismo e o império queriam renovar, proclamando que a religião não é mais o Estado, e que obedecer a César não é o mesmo que obedecer a Deus. (COULANGE, 1961, p. 355/356).
\end{abstract}

Reflexo importante desta percepção, qual seja, a de que existe um "império divino" e um "império terreno", e que o sacerdote não figura mais como chefe de Estado, é a quebra da identificação do imperador com a divindade. Não se percebe mais no imperador a figura do Augustus, do divino. Deixa o imperador de ser aquele que possuía os decretos de Deus sobre os homens. A partida daí, obedecer ao imperador não significava mais a mesma coisa que obedecer à divindade.

O Cristianismo cria, assim, o homem que tem relacionamentos distintos com o Estado e com a Divindade. O calendário, o banquete, as festas, as normas religiosas com efeitos civis, o imperador, o sacerdote, tudo começa a ser ressignificado com o Cristianismo. Todavia, essa vitória do cristianismo sobre a cultura religiosa da cidade, em que pese a expressa dicotomia apresentada por Jesus acerca de seu reino e do reino deste mundo, não foi suficiente para que, de fato, houvesse uma separação entre o ambiente civil e 0 ambiente religioso, sendo certo que o que ocorreu se deu em caminho oposto ao caminho ensinado por Jesus.

RC: 91482

Disponível em: https://www.nucleodoconhecimento.com.br/teologia/luz-da- 
O que aconteceu foi que a religião cristã esteve por um longo tempo perseguida, passando a existir sob forte intolerância estatal. Com as transformações culturais ocorridas em razão de um ensino que apregoava os valores cristãos, bem como pelo caráter revolucionário da mensagem de Jesus, o cristianismo não tinha como inimigo manifesto apenas o Estado. Levantou-se contra o cristianismo os poderes religiosos que viram seus prestígios ruírem diante da expansão dos valores cristãos por todo o mundo.

A perseguição aos cristãos, após deixar muitos mortos, e fazer com que alguns se afastassem das suas práticas cristãs sem, contudo, serem angariados para novas práticas religiosas, teve fim com a figura de Constantino que, após revelação acerca de um sinal sobre o qual venceria a batalha sobre a ponte de Mérvia, desafiou a maioria de seus súditos e passou a considerar a Igreja Cristã como fundamental para a cidade. Com isso, após crescente percentual de adeptos ao cristianismo, os próximos séculos viram um cristianismo construído sob as bases do poder estatal. É nesse momento que Constantino, segundo Veyne (2011), coloca a Igreja no centro do Império:

Desde as famosas histórias referentes as perseguições realizadas por Saulo para a captura dos Cristãos, sendo, depois, agora como Paulo, vítima da própria perseguição que antes defendia, o Cristianismo se criou como uma religião marginal, sem templo, sem local para adorar, sendo percebido como um movimento pagão. Todavia, é no século IV, com a conversão de Constantino, que o cristianismo, antes perseguido, assume protagonismo junto ao poder estatal. De perseguido, com o tempo, conforme atesta Veyne (2011), o cristianismo encaminhou para ser uma instituição forte e dominante dentro dos poderes do Estado.

Com o tempo, as transformações pelas quais o Estado passou levaram ao controle da moral, da cultura e da religião pelo cristianismo. Não havia autonomia social, ficando sobre o chefe da Igreja Católica os poderes temporais e espirituais.[2]

RC: 91482

Disponível em: https://www.nucleodoconhecimento.com.br/teologia/luz-da- 
O oriente do mundo antigo foi o palco em que a Igreja cristã inicia sua história (Dreher, 2002). Contudo, em 1486 que pela primeira vez foi adotado o termo Sacro Império Romano-Germânico para identificar essa formatação entre Igreja e Estado. Identificar essa instituição como "Sacro Império" vai além de uma simples nomenclatura, servindo para, de fato, mostrar a noção de um domínio superior deste império sobre todo o cosmo. Trata-se de uma sub-rogação do poderoso Império Romano para o, então, agora poderoso Sacro Império Romano-Germânico. Como exemplo, tem-se que foi na figura de Carlos Magno, como primeiro regente ocidental da idade média, coroado pelo próprio Papa, ainda no século VIII, que se traz a ideia de que o poderoso Império Romano passa a ser substituído pelo Império RomanoGermânico. A coroação do rei pelo Papa foi ato que passou a ser comumente repetido pelos próximos imperadores, sendo que, com isso, o rei não seria simplesmente um Imperador, mas alguém que tem sobre si a graça, um poder transnacional e uma dignidade salvadora.

A participação da Igreja no centro do Império deu-se em um período marcado por grandes movimentos, dentre eles, houve um período de militarização da Igreja (foram mais de 7 (sete) cruzadas). Além disse, a busca pelo conhecimento teológico passou a questionar essa participação da Igreja Cristã no, e com o, Estado. Nesse processo, o direito profano surge apartado da teologia, o que fez com que se visualizasse uma contradição entre a teologia e a dominação política, iniciando, assim, o processo de secularização.

É Marsílio de Pádua que, em 1324, tenta afastar o sacerdote do império, uma vez que o sacerdote teria legitimidade para Leis Divinas que não seriam coercitivas, o que seria contrário a lei humana que impõe castigo. Por ser a lei objeto de obediência do povo, e que busca o bem comum dos cidadãos, tal poder deve ser destacado do papa e passado exclusivamente ao imperador. Não bastasse, além de contradição sobre a ortopraxia da Igreja, já se percebia uma tensão existente entre a riqueza da Igreja e os preceitos cristãos que, além de tudo o que foi dito, não

RC: 91482

Disponível em: https://www.nucleodoconhecimento.com.br/teologia/luz-da- 
sustentavam a infalibilidade do papa ou da Igreja Romana (MIRANDA, 2017). É a partir do século $X$, com a força política da Igreja Romana, que passou a existir na Europa uma organização política singular cujo nome, conforme estabeleceu-se como o Sacro Império Romano.

Desde o século dez até ao décimo-nono existiu na Europa uma organização política singular, que demonstrou possuir características diferentes nas várias gerações. O nome oficial dessa organização era este: Sacro Império Romano, ainda que em forma comum, porém incorreta, era denominado Império Germânico. Até à sua aparição, a Europa situada ao oeste do Mar Adriático vivia em completa desordem, governada que era por tribos guerreiras em lugar de ser governada por Estados. Apesar de tudo, em meio a tanta confusão, o antigo conceito romano de ordem e unidade permaneceu como aspiração por um império para ocupar o lugar do Império Romano que, mesmo desaparecido, ainda era tradicionalmente venerado. (HURBULT, 1979. p. 141).

A cidade, então, parecia retornar aos valores iniciais que fomentaram a relação da religião com a cidade, qual seja, a reunião em torno de um sacerdote instituído por Deus e que, por isso, deve ser obedecido, não apenas por ser imperador, mas por ser o sacerdote da cidade.

É nesse ambiente que a Reforma Protestante ocorre, iniciada na Alemanha e se espalhando por todo o norte da Europa. A invenção da imprensa, o espírito nacionalista da Europa contra a autoridade estrangeira sobre suas igrejas, destacando a possibilidade de reduzir o poder eclesiástico, foram os primeiros passos para o processo da Reforma Protestante. Foi João Tetzel[3] que, sobre as bençãos de Leão $X$, passou a vender bulas assinadas pelo Papa que tinha por objetivo conceder perdão aos possuidores da bula, seus amigos, mortos ou vivos. É contra Tetzel que Lutero se levanta. Com as teses suscitadas por Lutero, a Europa sofre sobremaneira os efeitos da Reforma que se espalha de modo não uniforme por todo o seu continente iniciando um processo de abertura e desvinculação entre a Igreja e o poder do Estado. É nesse momento que, como nunca, abre-se espaço para o processo de secularização.

RC: 91482

Disponível em: https://www.nucleodoconhecimento.com.br/teologia/luz-da- 
Destaca-se que não foi apenas na Alemanha que o espírito da reforma se instalou, sendo certo que tal movimento encontrou acolhida em diversos países da Europa. Como exemplo, segundo Hulbert (1979), enquanto na Itália e Espanha o movimento era sufocado, na França e nos Países-Baixo a causa da Reforma era incerta, mas ao norte, a nova religião se fez vitoriosa.

É a reforma um movimento de profundas transformações políticas e sociais, não sendo, contudo, causadora, por si, de tais acontecimentos. A Reforma aprofunda mudanças que já existiam, fruto de diversos movimentos de seu tempo sendo que, em que pese os fortes reflexos da Revolução Francesa sobre a modernidade, consta a Reforma como sua propulsora, propulsora da subjetividade.

O filósofo alemão Georg W. F. Hegel, advogava a ideia de que a Modernidade teve o seu início a partir da Reforma e não, primeiramente, da Revolução Francesa (DICKEY, 2014, p. 358). Não desconsiderando o debate que Hegel promove em torno da Revolução Francesa, procuramos o lugar da Reforma no pensamento do filósofo alemão para o que se propõe nesse momento. Quando Jürgen Habermas (1989, p. 28) pontua o surgimento da Modernidade para Hegel a partir da Reforma, ele o faz a partir de uma chave de leitura, qual seja, a subjetividade - "Hegel descobre em primeiro lugar como princípio da ldade Moderna a subjetividade". (GONÇALVES, 2017, p. 53).

Apesar desse novo modelo para a prática da religião cristã, o cristianismo passou a ser percebido como uma religião cujo seu fim se aproximava. Era o Cristianismo, dessa sorte, em razão da modernidade, do individualismo e da reforma, fadado a um termo final. Era uma superação da crença, uma superação do sobrenatural.

Joas (2014: 13) e Stark (1999: 249) citam Thomas Woolston, teólogo e pensador livre inglês, como um dos primeiros expoentes da ideia de que a religião (cristã) teria um futuro limitado. Woolston escreveu na década de 1710 que, por volta do ano de 1900, o cristianismo desaparecia. (MONIZ, 2019, p. 53).

Assim, a relação entre a o cristianismo e a cidade revela, em Jesus, um novo modelo de relacionamento entre o sacerdote e o Estado. Todavia, após inúmeras

RC: 91482

Disponível em: https://www.nucleodoconhecimento.com.br/teologia/luz-da- 
perseguições sofridas pelos cristãos, essa relação intima entre o sacerdote e a cidade volta a ocorrer fazendo com que a lgreja Cristã, de perseguida, passasse a ser o centro de todo um império, qual seja, o Sacro Império Romano-Germânico que sub-rogou o Império Romano em força. Essa união entre o cristianismo e o Estado levantou fortes questionamentos, gerando uma busca por um conhecimento que se fazia distante do domínio intelectual da religião levando a um afastamento das normas religiosas das normas de direito civil, passando a surgir em vários locais da Europa o movimento de reforma que questiona, entre tantas outras coisas, a autoridade do sacerdote e da igreja sobre a cidade.

É na transformação do mundo que separa o sacro do profano que surge um novo "modo de ser" em que há a emancipação do conhecimento, da moral e do direito da religião. Trata-se do processo de secularização.

\section{A SECULARIZAÇÃO}

O estudo do termo "secularização" deve levar em consideração que ele pode oferecer uma universalidade de possibilidades para compreensão acerca do fenômeno que o envolve. Referida palavra pode ser mais bem estudada quando se percebe uma diversidade de perspectivas históricas-antropológicas sobre o tema. Em um primeiro momento deve-se levar em consideração o momento histórico em que se busca sua conceituação:

De acordo com alguns estudiosos, a carga semântica da palavra saeculum (de secus ou sexus) ainda requer novas exegeses histórico- -antropológicas, em ordem a explorar-se as possíveis ligações linguísticas nela implicadas, em particular as existentes entre sexo, geração, idade do homem, tempo de governo, duração da vida, período máximo de cem anos etc. (CATROGA, 2004, p. 52).

Em um segundo momento, deve-se perceber o fenômeno da secularização para além de um único contexto social, ou seja, não se trata de um tema afeto apenas a religião, mas é afeto ao direito, à filosofia, à sociologia, à economia, ao público, ao

RC: 91482

Disponível em: https://www.nucleodoconhecimento.com.br/teologia/luz-da- 
privado. A secularização serve como uma forma de ressignificação dessas áreas, realocando o publico, o religioso e o privado, diferenciando, nos termos de Catroga (2004), o domínio político do espiritual.

Em um terceiro momento, a secularização serve para identificar o tempo caracterizado como o "agora". Serve para identificar um ambiente físico, o profano, separando-os, assim, do sacro, do eterno, do espiritual. Trata-se, conforme Catroga (2004), de uma qualificação para os pagãos separada da figura dos clérigos. O termo "secular" também passou a ser usado para definir atividades não orientadas para a salvação. Tal fato gerou um recorte dentro da Igreja uma vez que identificava aqueles que poderiam servir com a entrega dos sacramentos, mas não possuíam o carisma do Espírito Santo:

Em uma perspctiva histórica, é possível dizer que a secularização se estabeleceu não apenas como um fenômeno garantidor das liberdades individuais, mas, também, como um fenômeno jurídico-político importante na construção da vida social das comunidades em seus mais diversos panoramas estruturais. Trata-se do distanciamento da religião do centro do poder estatal, realocando-a em um espaço de igual estatura de outros discursos, gerando um processo de autonomia do discurso religioso, sem, contudo, extirpar outros modos de ver o mundo. Com a secularização o Estado não mais é aquele que detém conhecimento e direcionamento do mundo conforme prescreve o ser transcendente que o orienta, ou seja, há uma transferência de centralidade entre o homem e a divindade, com aquele ocupando o centro das decisões. Nesse contexto, por questões multifatoriais, observa-se que a secularização se torna um fenômeno cuja análise depreende um olhar contextual complexo. Primeiro, porque a relação estado/divindade não se faz recente, ao contrário, parece acompanhar o homem desde sua criação e, segundo, porque o Estado se emancipa da religião por meio de diferentes modos de ser político, social e cultural.

RC: 91482

Disponível em: https://www.nucleodoconhecimento.com.br/teologia/luz-da- 
O processo que revela fenômeno da secularização se dá com as bases dos pensamentos que viabilizaram a modernidade. É com a chamada modernidade que a secularização ganha vida. Souza (2012) indicou essa relação da secularização com a modernidade sendo aquela, a secularização, um fenômeno peculiar desta.

As transformações decorrentes da modernidade, trazendo uma nova percepção acerca do papel do Estado nas suas estruturas sociais, não deixaram de fora a religião e suas instituições. Não se pode dizer que tais alterações tiveram uma base física, ou seja, são filhas de um lugar específico. Referidas alterações, conforme Moniz (2017), são frutos de um espírito daquela época.

Nesse contexto da impossibilidade de indicar um local físico e estático sobre a origem da secularização, também se pode dizer que a secularização não é fruto de um movimento único, como o declínio da religião. A secularização está dentro de um processo que antecede o próprio movimento do cristianismo:

Tal como Marramao (1998: 13), Kate (2015: 207) explica que as origens da secularização têm pouco a ver com a ideia corrente de declínio da religião. Pelo contrário, as suas raízes poderiam ser encontradas no processo de lenta transformação da revolução axial e no advento do cristianismo, mais especificamente, no étimo protocristão saeculum (e na sua metamorfose, acrescentaria Marramao). A secularização seria, portanto, parte deste legado, bebendo das suas conquistas, dilemas e fracassos. (MONIZ, 2017, p. 134/135).

Quando se diz que a secularização é revelada com a modernidade, significa que aquele novo modo de ver o mundo, cultural, social, econômico e politicamente, gerou, dentre tantos outros efeitos sociais, o fenômeno de alterar a relação entre o Estado, a Igreja, a propriedade privada e o espaço público. Não se pode, assim, prender referido fenômeno, o da secularização, apenas ao evento religioso, ou jurídico, mas sim, a secularização pode ser vista como fruto da soma de todos os fenômenos que levaram ao renascimento da arte, da filosofia, da cultura, dentre tantos outros.

RC: 91482

Disponível em: https://www.nucleodoconhecimento.com.br/teologia/luz-da- 
O fenômeno histórico-social da secularização está intimamente relacionado com o avanço da modernidade. O direito, a arte, a cultura, a filosofia, a educação, a medicina e outros campos da vida social moderna se baseiam em valores seculares, ou seja, não religiosos. As bases filosóficas da modernidade ocidental revelam uma concepção de mundo e de homem dessacralizadora, profana que contrasta com o universo permeado de forças mágicas, divinas das sociedades tradicionais e primitivas. $O$ desenvolvimento da ciência, da técnica e do racionalismo faz recuar as concepções sacrais e religiosas do homem e mundo. (RANQUETAT JR, 2008, p. $66)$.

O fenômeno da secularização, ainda, conforme Stigar e Ruthes (2010) é aquele que, sem negar a dimensão religiosa do ser humano, acomete um declínio às religiões, não só afastando-a do Estado mas, também, assumindo um tipo de espiritualidade individual na qual deixamos a igreja de lado e encaramos o demônio para nos salvar. É uma realocação do público e do privado. O Ministro do Supremo Tribunal Federal, Luis Roberto Barroso, bem esclarece acerca dessa divisão entre o público e o privado, destacando, ainda, a existência de uma vida política exercida em comunidade:

\begin{abstract}
A partir de então, todo cidadão passa a pertencer a duas ordens de existência: além de sua vida particular, privada, toma parte também na vida política, com o estabelecimento da distinção entre o que é seu próprio e o que diz respeito a todos54. O jardim e a praça, em uma imagem poética55. O espaço privado, pela tradição e pela lei, era o espaço do arbítrio: do marido, do pai, do senhor56. Foi na esfera pública que se iniciou a aventura humana em busca da liberdade, o embate inacabado entre o despotismo e a civilização. Mais recentemente, aguçou-se a percepção de que o público não se confunde com o estatal. Tal constatação se manifesta em planos diversos. (BARROSO, 2010, p. 80).
\end{abstract}

O que parece é que, no processo de secularização, a fusão entre Estado e a Igreja, com o consequente controle da produção intelectual, de valores morais impostos pela religião, é transformada por força de novos valores frutos da queda do monopólio religioso e do mundo mágico.

RC: 91482

Disponível em: https://www.nucleodoconhecimento.com.br/teologia/luz-da- 
A secularização não se prende apenas ao fenômeno Estado $\times$ Religião. Embora, mesmo que de relance, seja possível imaginar que no ambiente da secularização não exista religião, ou que ela não se manifeste, não parece que isso efetivamente ocorra, uma vez que a ideia sobre o desencantamento do mundo não significa a perda da religião, mas sim, uma forma de moralizá-la.

Dizer que a religião não perece com a modernidade, mas sim migra para o espaço privado da vida, parece ter sido fator importante para a manutenção do regime democrático. Isso ocorre porque, como afirma Mariano (2011) a religião, em certo ponto, poderia oferecer oposição em razão da sua intolerância.

O que se tem, assim, com o fenômeno da secularização é a emancipação da filosofia, da arte, da cultura e do direito de todo o movimento teológico. É a ciência construindo vida distante da teologia. Toda essa emancipação passa a servir como modo de enfraquecimento das forças políticas religiosas, transformando a realidade social, cultural, econômica e científica. Destaca-se, então, uma ética individualista com foco na liberdade (ANDRADE, 2015). Não há morte da religião, mas sim, há uma redefinição sobre o público e o privado, sobre religião e do Estado.

\section{O REINO DE DEUS E A CIDADE}

Vários são os textos bíblicos em que se pode extrair questões relativas ao Reino de Deus. Talvez, como se fez por muito tempo, muitas pessoas ao lerem esses versículos atribuam o conceito de Reino a um determinado trabalho ou tarefa a ser realizado no mundo, mais especificamente no Templo, ou seja, buscar o Reino seria executar atividades religiosas organizadas pela comunidade. Assim, dirigir um culto, ministrar o louvor, liderar grupos pequenos seria uma forma de buscar o Reino e sua Justiça. Com o tempo, percebe-se que o Reino não é assim, o Reino não parece mais um espaço físico ou uma atividade puramente religiosa.

Então, o que seria o Reino de Deus?

RC: 91482

Disponível em: https://www.nucleodoconhecimento.com.br/teologia/luz-da- 
Para Tolstoi (1894) o Reino de Deus seria todo aquele que se estabelece com base na premissa cristã em que o mal não se pode pagar com o mal, mais precisamente, Tolstoi (1894) falava sobre a não resistência do mal com violência. O que dizia referido autor, com base em Mateus 5: 39-42[4], era que, se for para reagir, que o homem faça o bem para pagar o mal, então o Reino seria um não reagir contra o mal com o próprio mal, como se fazem nas guerras. Embora a ideia de paz, ou de não resistência do mal com o mal seja uma ideia interessante, merece ressalva por dois motivos, primeiro pelo fato de não considerar que o Reino de Deus se estabelece com Justiça do próprio Reino e não com a do homem, segundo, o Reino de Deus não é apenas uma reação do homem, mas, também um fazer de Deus.

Ribeiro (2005) define o homem como um promotor da vontade de Deus que tem por objetivo fazer da terra uma extensão do céu, ou seja, o Reino seria um projeto inicial da criação no qual Deus encampa seu Reinado na Terra por meio do homem, a quem referido autor atribui a condição de Rei. Todavia, o Reino não deve ser compreendido como uma extensão do céu sendo o homem como um rei que promove esse reino na terra. Ora, o céu é o céu e a terra é a terra, não se faz do céu terra, e nem da terra céu, tampouco se faz Rei quem promove reinado de outro. Ademais, se a terra e o céu passarão[5], o Reino de Deus, então, não é um espaço físico.

Botas (1973), por sua vez, trabalha a discussão acerca do conceito de Reino com base nas parábolas relativas ao Reino de Deus como o grão de mostarda, como fermento e como uma rede[6]. Sendo assim, o Reino de Deus seria um processo natural, por ser uma realidade vívida, e também é um processo histórico em que há apelo para que os homens tenham discernimento e ajam na história transformando-a para o bem de todos. O Reino de Deus como processo natural de transformação e envolvimento humano para implementação de um bem na história, também não parece ser o que Jesus dizia ao falar sobre o Reino, isso ocorre porque, ao dizer que o Reino é uma pequena semente que brota, por exemplo, Jesus aponta para um

RC: 91482

Disponível em: https://www.nucleodoconhecimento.com.br/teologia/luz-da- 
Reino cujo fruto independe do homem, ou seja, o homem não é o centro do Reino, não é o homem quem implanta o Reino, quem implanta o Reino é o seu Rei.

Master (1973) parece chegar próximo sobre o que Jesus dizia quando falava sobre o Reino, qual seja, de que o Reino de Deus acontece quando Deus começa a tomar conta de tudo. O que é mais inclinado ao conceito de Reino de Deus na presente afirmação é o simples fato de que no Reino de Deus é Deus quem toma conta de todas as coisas e a vida caminha para o propósito dEle.

Munroe (s.d.) é preciso sobre o tema, definindo o Reino de Deus como o governo de Deus, o domínio de Deus sobre a terra e o céu, é sua vontade sendo executada em toda a criação.

Como se vê, no Reino de Deus há somente um protagonista, Deus. Não há um homem Rei, não há um homem bom ou mal, nem, tampouco, um homem que intervém na história. O que há é apenas um Deus, um governo e só.

Em que pese essa ideia acerca do Reino de Deus e laicidade, é possível observar que o tema "Reino de Deus e a cidade" é sensível tendo em vista que alguns acontecimentos que ocorrem na cidade geram na comunidade cristã a sensação de que, finalmente, a Igreja conseguiu ocupar seu lugar, o lugar de cabeça e não de calda. Como exemplo, bastaria a afirmação de que há algum cristão nos altos cargos eletivos do Estado para que se pudesse concluir que, finalmente, o Reino de Deus seria manifesto. Logo, a percepção que se tem desse governo de Deus sobre todas as coisas estaria ligada a integralização de "políticas do Reino "por meio, e nas "políticas dos homens".

Todavia, na cidade, não parece ser esse o espaço público que a Igreja, enquanto comunidade, deve priorizar, qual seja, o espaço de, e do, poder quando se fala em Reino. Não se quer dizer que a Igreja não comunique com tais ambientes, mas, sim, que lá não pode ser o seu destino, sua meta.

RC: 91482

Disponível em: https://www.nucleodoconhecimento.com.br/teologia/luz-da- 
John Stott (2019), por exemplo, afirma que os Cristãos podem adotar duas posturas em relação ao mundo (i) fuga ou (ii) envolvimento. Como conceito de envolvimento, afirma este ser um modo de ser em que se olhar para o mundo com envolvimento e compaixão. Como exemplo de sujar as mãos observou que os missionários levaram medicina, educação, técnicas agrícolas como expressão de missão e compaixão. Os objetos dessas lutas eram a injustiça e a opressão em nome do evangelho, sendo que sua missão não era apenas de palavras, mas de palavras e de atos em uma reponsabilidade social que acaba culminando em uma ação política que, sem critério, poderá gerar uma politização do evangelho.

Por isso, é possível concluir que em um ambiente secularizado, laico, mas com forte tradição religiosa, a Igreja não deve agir como uma comunidade que se prepara para assumir o poder como uma forma de implementar o Reino. Como ensina Kivitz (2006) a Igreja age em um lugar que denominou como "comum-pão", sendo que o Reino seria a vontade de Deus executada como um modo de ser do homem na sociedade e na comunidade.

\section{CONSIDERAÇÕES FINAIS}

O que se pode perceber nessa relação entre religião, cidade e o Reino de Deus é que este, o Reino, é um modo de ser, não é uma potestade, como muitos queriam que fosse. É o governo que se consolida em um fazer que é supraestatal, não é uma Igreja Oficial, um programa político, um presidente evangélico ou um pastor deputado. O Reino de Deus está, mesmo se lá ninguém estiver, o Reino de Deus é dinâmico e é sobre toda a criação. O Reino é como semente, das menores, mas, quando grande, torna-se a maior de todas de sua espécie, servindo como ninho e sombra para todos os pássaros que voam no céu, ou seja, é na simplicidade da existência que o Reino faz sombra.

RC: 91482

Disponível em: https://www.nucleodoconhecimento.com.br/teologia/luz-da- 


\section{REFERÊNCIAS}

ANDRADE, Camila Damasceno de. O Processo de Secularização do Pensamento Jurídico. Captura Críptica: direito, política, atualidade. Florianópolis, n. 4., v.2., jan./dez. 2015. p231-248.

BARROSO. Luis Roberto. Curso de Direito Constitucional Contemporâneo. Os conceitos fundamentais e a construção de um novo modelo.

CARTROGA, Fernando. Secularização e laicidade: uma perspectiva histórica e conceptual. Revista de História das Ideias. Tolerâncias, Intolerâncias. Instituto de História e Teorias das Ideias, Faculdade de Letras da Universidade de Coimbra. Vol. 25. 2004.

COULANGES. Numa-Denys Fustel de. A Cidade Antiga. Edittora das Américas EDAMERIS, São Paulo, 1961. Versão para eBoock.

DREHER. Martin N. Coleção História da Igreja Volume 1. A Igreja no Império Romano. $4^{\mathrm{a}}$ edição editora sinodal. 2002.

KIVITZ, Ed René. Outra espiritualidade: Fé, Graça e resistência. Mundo Cristão. 2006.

FAUSTO. Boris. História do Brasil. EdUsp. 12ª Edição. 2006.

FERREIRA, Franklin. A igreja cristã na história: Das origens aos dias atuais. Editora Vida Nova. 1르 Edição 2013.

FUKUYAMA, Francis (2013). As origens da ordem política. Dos tempos préhumanos até a Revolução Francesa. Rio de Janeiro: Rocco, 2013. 589 p 78.

RC: 91482

Disponível em: https://www.nucleodoconhecimento.com.br/teologia/luz-da- 
GABATZ. Celso. O Estado Laico e a Liberdade Religiosa no Brasil: o Acordo Brasil - Santa Sé e a "Lei Geral das Religiões". Direitos Culturais. Santo Ângelo, v. 13 , n. 29 , p. 47-66 jan/abr. 2018.

GONÇALVES. Alonso S. REFORMA E PLURALISMO RELIGIOSO: ANTECEDENTE DE UMA RELAÇÃO. Fronteiras: Revista de História | Dourados, MS | v. 19 | n. 34 | p. 49 - 70 | Jul. / Dez. 2017.

HURLBUT. Jesse Lyman. História da Igreja Cristã. 1979. Editora Vida.

IGREJA. Memórias da Ditadura. Disponível em http://memoriasdaditadura.org.br/igreja/. acesso em 15.05.2021.

LENZA. Pedro. Direito Constitucional Esquematizado. 24 edição. Editora Saraiva. 2020 .

LIMA. Lana Lage da Gama. O Padroado e a Sustentação do Clero no Brasil Colonial. Seculum. Revista de História [30]. João Pessoa. jan./jun. 2014.

MIRANDA, Maressa da Silva. RECONHECIMENTO E SECULARIZAÇÃO: A relação entre Estado, Igreja, Política e Religião e a construção da laicidade Brasileira. Tese (doutorado em ciência política). Universidade Federal de Minas Gerais. 2017.

MARIANO. Ricardo. Laicidade à Brasileira. Católicos, pentecostais e laicos em disputa na esfera pública. Civitas. Porto Alegra. V. 11. n. 2. p 238-258. maio-ago. 2011.

MONIZ. Jorge Botelho. Genealogia da Tese da Secularização: Da sua proveniência pré-sociológica à emergência na sociologia do Século XIX. Revisa Sociedad y Religion. N. 48.Vol. XXVII (2017). P 130-163)

RC: 91482

Disponível em: https://www.nucleodoconhecimento.com.br/teologia/luz-da- 
MUNROE. Myles. Aplicando o Reino de Deus. Redescobrindo a prioridade de Deus para a humanidade. Série Princípios do Reino. S.d.

PROENÇA. Wander de Lara. História do Cristianismo III, Faculdade Sul Americana. 2020.

RANQUETAT JR. César. Laicidade, Laicismo e Secularização: Definindo e Esclarecendo Conceitos. Revisa Sociais \& Humanas. CCSH/UFSM. v. 21. n. 1. 2008

SOUZA, Bertone de Oliveira. Secularização: Uma discussão sobre suas características e Manifestações no mundo contemporâneo. Revista Espaço Acadêmico. N. 132. Maio de 2012.

RIBEIRO, Eneas. O Reino de Deus, de volta à vida abundante. \#UP BOOKS, São Paulo, junho de 2015.

STOTT, John R. W. O cristão em uma sociedade não cristã. Rio de Janeiro. Thomas Nelson, Brasil, 2019.

STOTT, John R. W. Crer é também pensar. Rio de Janeiro. Thomas Nelson, Brasil, 2019.

TOLSTOI, Leon. O Reino de Deus Está em Vós. Rosa dos Tempos. 2ª Edição.

VEYNE. Paul. Quando Nosso Mundo se Tornou Cristão [312-394]. 2 $2^{a}$ Edição. Civilização Brasileira. 2011.

VOUX. R. de. Instituições de Israel no Antigo Testamento. Tradução Daniel de Oliveira. 2003. Editora Teológica.

\section{APÊNDICE - REFERÊNCIA DE NOTA DE RODAPÉ}

RC: 91482

Disponível em: https://www.nucleodoconhecimento.com.br/teologia/luz-da- 
2. É em Gregório I, chamado o Grande, que surge a figura do papado. Gregório possuía grande respeito pela comunidade, escrevia sobre questões religiosas que servirão como influência para o seu tempo, constituindo-se patriarca do Ocidente.

3. Tetzel fazia esta afirmação ao povo: "Tão depressa o vosso dinheiro caia no cofre, a alma de vossos amigos subirá do purgatório ao céu." (HURBULT, 1979, p. 176)

4. Eu, porém, vos digo: não resistais ao perverso; mas, a qualquer que te ferir na face direita, volta-lhe também a outra; e, ao que quer demandar contigo e tirar-te a túnica, deixa-lhe também a capa. Se alguém te obrigar a andar uma milha, vai com ele duas. Dá a quem te pede e não voltes as costas ao que deseja que the emprestes.

5. Passará o céu e a terra, porém as minhas palavras não passarão

6. Mateus 13: $31-33,47-50$

Enviado: Março, 2021.

Aprovado: Julho, 2021.

RC: 91482

Disponível em: https://www.nucleodoconhecimento.com.br/teologia/luz-da- 